\title{
ANALISIS STRATEGI RETRIBUSI DAERAH SEKTOR PARIWISATA KABUPATEN GOWA
}

\author{
Ardian \\ Dinas Pariwisata Kabupaten Gowa \\ Email : ardianleghari@gmail.com
}

Abd Rakhman Laba

Departemen Manajemen Fakultas Ekonomi dan Bisnis Universitas Hasanuddin

Email :jeneponto2000@yahoo.com

\author{
Andi Aswan \\ Departemen Manajemen Fakultas Ekonomi dan Bisnis Universitas Hasanuddin \\ Email : andiaswanp@yahoo.com
}

\begin{abstract}
Abstrak: Penelitian ini bertujuan untuk menentukan strategi yang tepat dan dapat implementasikan untuk meningkatkan penerimaan retribusi pada Dinas Pariwisata Kabupaten Gowa dengan mengkaji 6 objek wisata yang terdapat di daerah tersebut. Instrumen pengumpulan data menggunakan survey kuesioner, observasi dan wawancara terhadap 29 orang, kepala dinas, kepala divisi, pengelola objek wisata dan pengunjung. Data yang diperoleh dianalisa dengan menggunakan SWOT dan matriks IE untuk menentukan strategi dan posisi kepariwisataan sedangkan matriks QSPM digunakan untuk menentukan prioritas strategi. Hasil Analisis IE menunjukkan posisi Objek Pariwisata berada pada kuadran ke V yang berarti Hold and Maintain (jaga dan pertahankan). Strategi yang tepat yang digunakan adalah strategi intensif (penetrasi pasar dan pengembangan produk). Hasil analisis matriks SWOT didapatkan empat alternatif strategi, yaitu : (1) Penambahan sumber penerimaan retribusi baik berupa penambahan objek pariwisata maupun objek pendukung kegiatan pariwisata, (2) Alokasi Sumber Daya Manusia (SDM) sesuai dengan kompetensi yang dimiliki, (3) Optimalisasi kegiatan pemasaran, dan (4) Peningkatan Kesadaran wajib retribusi. Berdasarkan analisis QSPM, alternatif strategi yang tepat dan dapat dilakukan oleh pemerintah Kabupaten Gowa adalah memperluas jenis penerimaan retribusi.
\end{abstract}

Kata kunci: Strategi, Pendapatan Asli Daerah (PAD), Retribusi Daerah

\begin{abstract}
This study aims to generate possible strategies that can be implemented to increase amount of retribution income at the Department of Tourism in Gowa Regency by reviewing 6 tourism objects within the regency. Instruments used for data collection are survey questionnaires, observation, and semi structure interview conducted to 29 respondents comprising of head departments, heads of division, and managements of each tourism object, as well as customers. The collected data were analyzed by using SWOT and IE matrix as a basis for generating possible strategies and determine competitive position of the studied tourism objects. The QSPM is then used to rank the generated strategies for prioritization. The result of IE matrix showed that the position of the tourism objects is in quadrant V meaning that hold and maintain. The appropriate strategy used is intensive strategy (market penetration and product development). In SWOT matrix analysis, results obtained four alternative strategies, namely: (1) boosting amount of retribution by increasing numbers of tourism objects and supported tourism activities for customer attraction, (2) allocation of human resources in accordance with the competencies, (3) optimizing marketing activities, and (4) increasing awareness for retribution payment. Based on QSPM analysis, an appropriate strategy possibly implemented by Department of Tourism in Gowa Regency is expanding sources of retribution incomes.
\end{abstract}

Keywords: Strategies, Retribution Income, Tourism Objects. 


\section{Jurnal Bisnis, Manajemen dan Informatika}

\section{PENDAHULUAN}

Penelitian ini dilakukan sebagai bentuk dukungan kepada pemerintah dalam upaya untuk meningkatkan penerimaan retribusi sektor pariwisata di Kabupaten Gowa. Selama ini penerimaan sektor pariwisata di Kabupaten Gowa masih rendah dibandingkan dengan daerah lainnya, terutama Kabupaten Maros, Kota madya Makassar, dan Kabupaten Pangkep (Laporan Tahunan Dinas Kebudayaan dan Pariwisata Kabupaten Gowa Tahun 2015-2016). Untuk itu, penelitian ini mengkaji retribusi enam objek wisata di Kabupaten Gowa untuk menghasilkan berbagai strategi yang dapat diimplementasikan guna meningkatkan Pendapatan Asli Daerah (PAD).

Sebagaimana diketahui bahwa sumber pembiayaan dari PAD (Pendapatan Asli Daerah) memiliki komponen penerimaan yang berasal dari sektor pajak daerah dan retribusi daerah yang termaktub dalam Undang-Undang Nomor 34 Tahun 2000 tentang perubahan UU Nomor 18 Tahun 1997 (Purwadinata, 2010). Tidak hanya terkait dengan komponen saja, Undang-undang tersebut juga menjelaskan tentang kewenangan Daerah Kabupaten/Kota dalam menggali potensi sumber-sumber keuangannya dengan menetapkan jenis pajak dan retribusi selain yang telah ditetapkan.

Terkait dengan literatur, sejumlah penelitian ditemukan pernah mengkaji retribusi daerah sektor publik (e.g. Wahyudi, 2016; Kuncoro, 2016; Wibowo \& Utama, 2017; dan Pareang \& Yudea, 2016). Namun, dari sejumlah literatur tersebut, berdasarkan pengetahuan terbaik penulis, terdapat hanya sedikit jumlah penelitian yang pernah menguji penelitian sektor publik terkait dengan retribusi daerah menggunakan metode analisis SWOT dan QSPM (e.g. Fretes, 2013; Purwadinata, 2010; Yuningsih 2005; Nurhayati 2008). Hanya Richard A De Fretes (2013) yang berfokus pada penelitian sektor pariwisata dan hanya membahas kepariwisataan di tingkat kecamatan tepatnya di Kecamatan Leitimur Selatan Kota Ambon dengan judul "Strategi Perencanaan dan Pengembangan Industri Pariwisata Dengan Metode SWOT dan QSPM'.

Mengacu pada penelitian tersebut, penelitian ini kemudian dilakukan dengan metode serupa namun objek penelitian diperluas dengan jangkauan seluruh objek wisata di tingkat kabupaten, yaitu Kabupaten Gowa. Penelitian ini diarahkan untuk menjawab pertanyaan strategi apa saja yang dapat digunakan oleh pemerintah Kabupaten Gowa dalam meningkatkan retribusi sektor pariwisata dan bagaimana strategi tersebut tersusun berdasarkan prioritas.

\section{TINJAUAN LITERATUR}


Manajemen stratgik berkaitan dengan keputusan yang diambil oleh manajemen puncak dalam suatu organisasi, termasuk organisasi bisnis. Keputusan strategik tersebut diantaranya harus mampu untuk merumuskan dan menentukan strategi yang tepat untuk mempertahankan eksistensi organisasi. Keputusan strategik krusial lainnya adalah keputusan strategis yang dibuat agar organisasi bisnis mampu berdapatasi terhadap hal-hal yang krusial untuk mendorong efektifitas dan produktivitas organisasi (Siagian, 1995). Berbicara mengenai strategi, terdapat definisi yang luas dikemukakan oleh berbagai penulis. Siagian (2004) berpendapat bahwa strategi adalah serangkaian keputusan dan tindakan mendasar yang dibuat oleh manajemen puncak dan diimplementasikan oleh seluruh jajaran suatu organisasi dalam rangka pencapaian tujuan organisasi tersebut. Hal yang sama, Halim (2001) mendefisikan strategi sebagai suatu cara dimana sebuah lembaga atau organisasi akan mencapai tujuannya sesuai peluang dan ancaman lingkungan eksternal yang dihadapi serta kemampuan internal dan sumber daya. Selanjutnya, Nitisemito (1986) mendefisinikan sebagai rencana yang disatukan, luas dan berintegrasi yang mencakup keunggulan strategis perusahaan dalam menghadapi tantangan dari lingkungannya, yang dirancang untuk dapat memastikan tujuan dari perusahaan dapat tercapai.

Berdasarkan definisi tersebut dapat disimpulkan bahwa strategi merupakan suatu cara untuk mencapai tujuan organisasi melalui serangkaian keputusan yang telah dirumuskan dengan memperhatikan faktor internal dan faktor eksternal organisasi. Atas dasar itu dapat dikatakan bahwa cara yang paling terbaik, misalnya, untuk dapat meningkatkan sektor penerimaan suatu organisasi dapat dilakukan dengan cara mendorong upaya formulasi strategi (Donovan, 2016; Puspita, 2016). Hal ini juga tentunya dapat dilakukan dalam upaya untuk meningkatkan sektor penerimaan retribusi yang dikelola oleh berbagai instansi-instansi pemerintah, termasuk upaya peningkatan retribusi yang dikelola oleh Dinas Pariwisata.

Terkait dengan retribusi, pada umumnya peneliti memiliki definisi yang hampir sama satu dengan yang lainnya. Misalnya, menurut Siahaan (2006) retribusi daerah adalah pungutan daerah sebagai pembayaran atas jasa atau pemberian izin tertentu yang khusus disediakan dan atau diberikan oleh pemerintah daerah untuk kepentingan orang pribadi atau badan, sedangkan menurut Munawir (1995) retribusi adalah iuran kepada Pemerintah yang dapat dipaksakan dan jasa balik secara langsung dapat ditunjuk. Paksaan di sini bersifat ekonomis karena siapa saja yang tidak merasakan jasa balik dari pemerintah, dia tidak dikenakan iuran itu. Saragih (2002) berpendapat bahwa retribusi Daerah merupakan salah satu jenis penerimaan daerah yang dipungut sebagai pembayaran atau imbalan langsung atas pelayanan yang diberikan oleh Pemerintah Daerah kepada masyarakat. Berdasarkan hal tersebut dapat disimpulkan bahwa 


\section{Jurnal Bisnis, Manajemen dan Informatika}

retribusi adalah pungutan legal yang dilakukan oleh pemerintah atas penyajian pelayanan atau akses izin untuk orang pribadi ataupun badan.

Ciri-ciri retribusi daerah menurut Situmorang dan Sitanggang (1994) adalah: (1) Retribusi dipungut oleh negara, (2) Dalam pemungutan terdapat paksaan secara ekonomis (3) Adanya kontra prestasi yang secara langsung dapat ditunjuk, dan (4) Retribusi dikenakan pada setiap orang/ badan yang menggunakan/ mengenyam jasa-jasa yang disiapkan negara. Retribusi daerah dikelompokkan ke dalam tiga golongan berdasarkan sumber penerimaannya, yaitu retribusi jasa umum, retribusi jasa usaha, dan retribusi perizinan tertentu. Pariwisata adalah salah satu sumber retribusi yang tergolong dalam retribusi jasa usaha. Sektor pariwisata ini kemudian dipilih peneliti sebagai objek penelitian mengenai peningkatan penerimaan retribusi daerah. Pariwisata menurut Undang-Undang Republik Indonesia Nomor 10 Tahun 2009 Tentang Kepariwisataan adalah berbagai macam kegiatan wisata dan didukung berbagai fasilitas serta layanan yang disediakan oleh masyarakat, pengusaha, Pemerintah, dan Pemerintah Daerah (Yuningsih, 2005).

\section{LOKASI, SAMPEL, DAN METODE PENGUMPULAN DATA}

Penelitian ini berlokasi di Dinas Kebudayaan dan Pariwisata Kabupaten Gowa dan 6 objek pariwisata Kabupaten Gowa. Dalam penelitian ini, penulis menggunakan metode analisis SWOT untuk mengidentifikasi faktor internal dan eksternal dan QSPM untuk menentukan strategi prioritas yang sesuai dengan kondisi objek penelitian. Populasi dalam penelitian ini berjumlah 29 orang dengan sampel terdiri dari 5 orang pegawai Dinas Kebudayaan dan Pariwisata Kabupaten Gowa, 6 orang pengelola objek wisata, serta 18 orang pengunjung objek wisata yang dibagi ke dalam masing-masing 3 pengunjung tiap objek wisata. Dalam mengumpulkan data, penelitian ini menggunakan metode yaitu kuesioner berupa pemberian bobot 3 dan rating 4 terhadap indikator faktor internal dan eksternal (David, 2009).

Analisis data dilakukan melalui tiga tahap kerja yaitu tahap masukan (input stage), tahap pencocokan (matching stage), tahap keputusan (decision stage). Tahap pertama adalah tahap input di mana dalam penelitian ini menggunakan matriks IFE dan EFE. Proses selanjutnya adalah tahap pencocokan yang berfokus pada pembuatan alternatif strategi yang tepat dengan mencocokkan faktor internal dan eksternal. Alat analisis yang digunakan pada tahap pencocokan adalah matriks IE, dan matriks SWOT. Tahapan yang terakhir dilakukan analisis menggunakan matriks QSPM untuk menentukan keputusan strategi. 


\section{HASIL}

Berdasarkan identifikasi lingkungan internal diperoleh melalui wawancara dengan pihak Dinas Kebudayaan dan Pariwisata Kabupaten Gowa yaitu Kepala Dinas, Pengelola Objek Pariwisata dan Pengunjung Objek Pariwisata. Faktor internal dibagi ke dalam kekuatan (strength) dan kelemahan (weakness). Adapun faktor internal adalah : (1) Objek wisata yang beraneka ragam, (2) Objek yang dikenal secara nasional maupun internasional, (3) Keunikan objek wisata, (4) SDM memiliki kompetensi di bidangnya, (5) Aksesibilitas di setiap objek wisata lancar, (5) Pelayanan yang baik, dan (6) Pemasaran dilakukan secara optimal. Sedangkan faktor eksternal adalah : (1) Tarif retribusi di setiap objek wisata kecil, (2) Objek penerimaan retribusi sedikit, (3) Kurangnya SDM, (4) Sarana dan Prasarana belum memadai, (5) Jarak lokasi wisata jauh, (6) Proses setor retribusi masih manual, dan (7) Ketegasan dalam pemungutan retribusi masih rendah.

Selain identifikasi lingkungan internal, peneliti juga melakukan identifikasi lingkungan eksternal yang terdiri dari peluang (opportunity) dan ancaman (threat). Adapun peluang yang dimiliki adalah : (1) Sifat kepariwisataan yang suistainable, (2) Masih banyak objek retribusi yang belum dikembangkan, (3) Kebijakan pemerintah yang berorientasi pada sektor pariwisata, (4) Dukungan masyarakat di sekitar objek pariwisata, (5) Komitmen pemerintah dalam upaya peningkatan PAD dan (6) Kemajuan teknologi. Sedangkan ancaman yang dihadapi adalah : (1) Kesadaran pengunjung tentang wajib retribusi masih rendah, (2) Kesadaran pengunjung dalam menaati peraturan masih rendah, (3) Beberapa objek wisata bergantung pada kondisi alam, (4) Tuntutan terhadap kualitas objek pariwisata, dan (5) Objek pariwisata milik swasta berkembang pesat.

Setelah melakukan identifikasi faktor internal dan eksternal, tahap yang dilakukan selanjutnya adalah perumusan strategi. Adapun dalam tahap ini terdiri dari analisis matriks IFE dan EFE, kemudian analisis IE dan SWOT masuk dalam tahap pencocokan, dan tahap pengambilan keputusan menggunakan matriks QSPM.

Hasil analisis matriks IFE dan EFE dapat dilihat pada tabel 2 dan tabel 3. Berdasarkan tabel 2 analisis matriks IFE menghasilkan total nilai tertimbang sebesar 2,6425. Kekuatan utama dari strategi peningkatan PAD melalui retribusi sektor pariwisata di Kabupaten Gowa adalah pemasaran yang dilakukan secara optimal dengan skor sebesar 0,2942. Sedangkan kelemahan utama adalah objek penerimaan retribusi sedikit dengan skor sebesar 0,1136. Pada tabel 3 analisis matriks EFE menghasilkan total nilai tertimbang sebesar 2,8215. Kekuatan utama dari strategi peningkatan PAD melalui retribusi sektor pariwisata di Kabupaten Gowa adalah komitmen pemerintah dalam upaya peningkatan PAD dengan skor sebesar 0,3853. Sedangkan 


\section{Jurnal Bisnis, Manajemen dan Informatika}

kelemahan utama adalah kesadaran pengunjung tentang wajib retribusi masih rendah dengan skor sebesar 0,1205.

Setelah melakukan analisis menggunakan matriks IFE dan EFE, tahap selanjutnya adalah analisis IE yang digunakan untuk mengetahui posisi strategi peningkatan Pendapatan Asli Daerah (PAD) melalui retribusi sektor pariwisata di Kabupaten Gowa saat ini. Matriks IE didasarkan pada nilai tertimbang yang diperoleh dari matriks IFE dan EFE. Nilai tertimbang sebesar 2,6425 yang diperoleh dari matriks IFE dan nilai tertimbang sebesar 2,8215 diperoleh dari matriks EFE. Berdasarkan hasil analisis matrik Internal Eksternal (IE) dapat disimpulkan bahwa organisasi terdapat pada posisi sel V. Di mana terlihat bahwa organisasi berada pada posisi internal yang sedang dan eksternal yang sedang juga. Organisasi dapat digambarkan dalam posisi bertahan dan pencapaian (hold and maintain). Strategi yang dapat diterapkan antara lain strategi yang intensif penetrasi pasar dan pengembangan produk. Dari analisis yang telah dilakukan dan berdasarkan kondisi objek pariwisata saat ini strategi yang tepat untuk dilaksanakan adalah penetrasi pasar dan pengembangan produk.

Tahap selanjutnya adalah analisis dengan menggunakan matriks SWOT, dapat dilihat pada tabel 4. Analisis Matriks SWOT yang dilakukan menghasilkan delapan macam strategi yang dikelompokkan dalam empat sel, yaitu strategi S-O, strategi S-T,strategi W-O, dan strategi WT. Pada tahap ini, peneliti kemudian merumuskan 4 (empat) alternatif strategi, yaitu : (1) Penambahan sumber penerimaan retribusi baik berupa penambahan objek pariwisata maupun objek pendukung kegiatan pariwisata, (2) Alokasi Sumber Daya Manusia (SDM) sesuai dengan kompetensi yang dimiliki, (3) Optimalisasi kegiatan pemasaran, dan (4) Peningkatan Kesadaran wajib retribusi.

Tahap yang terakhir adalah tahap keputusan (decision stage) dengan menggunakan matriks QSPM, dapat dilihat pada tabel 5. Berdasarkan hasil analisis QSPM yang dilakukan, maka prioritas strategi yang harus dilakukan saat ini adalah menambah sumber penerimaan retribusi baik berupa penambahan objek pariwisata maupun objek pendukung kegiatan pariwisata, dengan STAS tertinggi sebesat 5,88. Adapun untuk selengkapnya masing-masing strategi diurutkan sebagai berikut : (1) Penambahan sumber penerimaan retribusi baik berupa penambahan objek pariwisata maupun objek pendukung pariwisata, (2) Alokasi Sumber Daya Manusia (SDM) sesuai dengan kompetensi yang dimiliki, (3) Optimasilasi Kegiatan Pemasaran, dan (4) Peningkatan Kesadaran Wajib Retribusi.

\section{PEMBAHASAN}

Analisis Matriks SWOT yang dilakukan menghasilkan delapan macam strategi yang dikelompokkan dalam empat sel, yaitu strategi S-O, startegi S-T,strategi W-O,strategi W-T. 
Stratesi S-O merupakan strategi yang memanfaatkan kekuatan yang dimiliki perusahaan untuk meraih peluang yang ada di lingkungan eksternal, guna keberhasilan tujuan organisasi. Adapun strategi yang dapat dilakukan adalah mempertahankan promosi objek wisata yang sejauh ini dinilai sudah optimal. Strategi promosi ini dapat dilakukan dengan memanfaatkan kemajuan teknologi dan dukungan pemerintah. Dengan adanya kedua faktor ini diharapkan dapat mendukung kegiatan pemasaran objek pariwisata yang akan berpengaruh terhadap penerimaan retribusi Kabupaten Gowa sektor pariwisata.

Strategi W-O adalah strategi yang mengatasi atau meminimalisir kelemahan yang dimiliki perusahaan untuk memanfaatkan peluang yang ada. Adapun strategi yang dapat dilakukan adalah menambah objek penerimaan retribusi atau sumber retribusi. Penambahan sumber penerimaan retribusi ini tidak hanya berupa penambahan objek wisata namun juga dapat berupa objek pendukung kegiatan wisata. Strategi ini diharapkan dapat membantu sektor pariwisata Kabupaten Gowa dalam meningkatkan penerimaan retribusinya. Strategi ini didukung oleh kebijakan pemerintah yang berorientasi pada sektor pariwisata dan komitmen pemerintah dalam upaya peningkatan PAD akan sangat membantu dalam proses penerapan strategi ini.

Strategi S-T adalah strategi yang menggunakan kekuatan organisasi untuk mengatasi ancaman yang dihadapi oleh organisasi. Adapun strategi yang dapat dilakukan adalah alokasi sumber daya manusia (SDM) di bidang yang tepat sesuai dengan kompetensi yang dimilikinya. Strategi ini diharapkan dapat menyelesaikan beberapa tantangan yang kerap dihadapi di lapangan, diantaranya adalah meningkatkan kesadaran pengunjung tentang wajib retribusi. Selain itu dengan alokasi SDM yang berkompeten dapat meningkatkan kualitas objek pariwisata serta dapat meningkatkan daya saing objek pariwisata di Kabupaten Gowa.

Strategi W-T merupakan strategi di mana organisasi dapat meminimalisir kelemahan dan menghindari ancaman. Strategi yang dihasilkan adalah adanya ketegasan pengelola dalam melakukan pungutan retribusi bagi pengunjung. Strategi ini diambil berdasarkan fakta di lapangan yang menunjukkan bahwa kesadaran pengunjung terhadap wajib retribusi masih rendah. Permasalahan ini juga didukung dengan rendahnya ketegasan pihak pengelolaan objek pariwisata dalam melakukan pungutan retribusi. Dengan adanya strategi ini diharapkan dapat menyelesaikan permasalahan yang ada, sehingga secara tidak langsung memberi kontribusi terhadap peningkatan PAD sektor pariwisata Kabupaten Gowa.

Analisis Matriks QSPM merupakan tahap keputusan yaitu tahap yang terakhir untuk menentukan strategi terbaik yang dapat dijalankan atau digunakan perusahaan dari alternatifalternatif strategi yang diperoleh dari hasil analisis SWOT. Berdasarkan hasil analisis QSPM yang dilakukan, maka prioritas strategi yang harus dilakukan saat ini adalah menambah sumber 


\section{Jurnal Bisnis, Manajemen dan Informatika}

penerimaan retribusi baik berupa penambahan objek pariwisata maupun objek pendukung kegiatan pariwisata. Strategi ini diharapkan dapat meningkatkan penerimaan retribusi sektor pariwisata melalui penambahan sumber-sumber penerimaan retribusi. Adapun sumber penerimaan yang dimaksud adalah berupa objek wisata yang belum dikelola langsung pemerintah, dan juga objek pendukung kegiatan pariwisata tang dapat dijadikan sebagai sumber penerimaan retribusi.

\section{KESIMPULAN DAN SARAN}

Berdasarkan hasil analisis matrik Internal Eksternal di atas dapat disimpulkan bahwa objek pariwisata Kabupaten Gowa terdapat pada posisi sel V. Objek wisata ini dapat digambarkan dalam posisi hold and maintain. Hasil analisis matriks SWOT didapatkan empat alternatif strategi, yaitu : (1) Penambahan sumber penerimaan retribusi baik berupa penambahan objek pariwisata maupun objek pendukung kegiatan pariwisata, (2) Alokasi Sumber Daya Manusia (SDM) sesuai dengan kompetensi yang dimiliki, (3) Optimalisasi kegiatan pemasaran, dan (4) Peningkatan Kesadaran wajib retribusi. Berdasarkan analisis QSPM. Alternatif strategi yang tepat dan dapat dilakukan oleh pemerintah Dinas Kebudayaan dan Pariwisata Kabupaten Gowa secara berurutan adalah : (1) Penambahan sumber penerimaan retribusi baik berupa penambahan objek pariwisata maupun objek pendukung kegiatan pariwisata (STAS : 5.88), (2) Alokasi Sumber Daya Manusia (SDM) sesuai dengan kompetensi yang dimiliki (STAS : 5.43), (3) Optimalisasi kegiatan pemasaran (STAS : 4.65), dan (4) Peningkatan Kesadaran wajib retribusi (STAS : 4.00). Sebaiknya pemerintah Dinas Kebudayaan dan Pariwisata Kabupaten Gowa melakukan strategi intensif (penetrasi pasar dan pengembangan produk).

\section{DAFTAR PUSTAKA}

David F.R. (2009). Manajemen Strategis Konsep. Jakarta: Salemba Empat.

Donovan, D. (2016). Strategi Pemungutan PBB Sebagai Upaya Meningkatkan Pendapatan Asli Daerah di Kota Mojokerto. Jurnal Ilmu dan Riset Akuntansi, 4(11).

Fretes R.A.D., Purnomo B., Santoso., Soenoko R. \& Astuti M. (2013). Strategi Perencanaan Dan Pengembangan Industri Pariwisata Dengan Menggunakan Metode SWOT dan QSPM (Studi Kasus Kecamatan Leitimur Selatan Kota Ambon). Malang : Universitas Brawijaya.

Halim A. (2001). Manajemen Keuangan Daerah. Yogyakarta : UPP AMP YKPN. 
Kuncoro, M. (2016). Desentralisasi fiskal sebagai alternatif menggali sumber dana pembangunan dan mewujudkan otonomi daerah. Economic Journal of Emerging Markets, 6(1), 22-34.

Laporan Tahunan Dinas Kebudayaan dan Pariwisata Kabupaten Gowa Tahun 2015-2016

Munawir S. (1995). Analisis Laporan Keuangan. Yogyakarta : Liberty.

Nitisemito, Alex S. (1986). Marketing. Ghalia Indonesia, Jakarta.

Nurhayati S. (2008). Pendekatan Qspm Sebagai Dasar Perumusan Strategi Peningkatan Pendapatan Asli Daerah Kabupaten Batang. Pekalongan : Universitas Pekalongan.

Pareang, Y., \& Yudea, Y. (2016). Analisa Kontribusi Pajak Daerah dan Retribusi Daerah Terhadap Pendapatan Asli Daerah (PAD) Kota Balikpapan (Studi Pada Kantor Dinas Pendapatan Daerah Kota Balikpapan. Jurnal Ekonomi Dan Bisnis, 18 (1), 33-41.

Purwadinata S. (2010). Analisis Potensi Pendapatan Asli Daerah Dan StrategiPeningkatan Kemampuan Keuangan Daerah di Kabupaten Sumbawa. Malang : Universitas Brawijaya.

Puspita, A. F. (2016). Analisis Penetapan Target Penerimaan Pajak Daerah (Studi pada Dispenda Kota Malang). Jurnal Administrasi dan Bisnis (adbis), 10(1), 25-38.

Rangkuti F. (2014). Analisis SWOT: Teknik Membedah Kasus Bisnis. Jakarta: PT Gramedia Pustaka Utama.

Saragih, J.P. (2002). Desentralisasi Fiskal dan Keuangan Daerah dalam Otonomi. Penerbit Ghalia. Jakarta.

Siagian, Sondang P. 1995. Manajemen Sumber Daya Manusia. Jakarta : PT. Elek Media Kompetindo.

Siahaan M.P. (2006). Pajak Daerah dan Retribusi Daerah. Jakarta : PT. Raja Grafindo Persada.

Situmorang V.M. \& Sitanggang C. (1994). Hukum Administrasi Pemerintahan Di Daerah. Jakarta : Sinar Grafika.

Wahyudi, M. V. (2016). Pengaruh Pajak, Retribusi Daerah, Dau, dan Dak Terhadap Alokasi Anggaran Belanja Modal. Jurnal Ilmu dan Riset Akuntansi, 4(11).

Wibowo, A. W., \& Utami, S. (2017). Dampak Undang-Undang No. 28 Tahun 2009 Tentang Pajak dan Retribusi Daerah Terhadap Pendapatan Asli Daerah dan Investasi di Kabupaten Sleman. Paradigma: Jurnal Ilmu Administrasi, 3(1), 22-43.

Yuningsih N. (2005). Peningkatan Pendapatan Asli Daerah (PAD) Melalui Pengembangan Potensi Obyek Wisata Pantai Pangandaran Di Kabupaten Ciamis Jawa Barat. Semarang : Universitas Negeri Semarang 
Tabel 1. Realisasi Penerimaan Retribusi Daerah Kabupaten Gowa, Kabupaten Pangkep, dan Kota Makassar Tahun 2015-2016

\begin{tabular}{llllc}
\hline \multirow{2}{*}{ No } & \multicolumn{1}{c}{ Kabupaten / Kota } & \multicolumn{2}{c}{ Tahun Realisasi } & $\begin{array}{c}\text { Persentase } \\
\text { Peningkatan } \\
(\%)\end{array}$ \\
\hline 1 & Kabupaten Gowa & 1015 & $\begin{array}{l}2016 \\
(\mathrm{Rp})\end{array}$ & $18 \%$ \\
2 & Kabupaten Pangkep & $200,100,000$ & $138,817.000$ & $-31 \%$ \\
3 & Kota Makassar & $116,600,000$ & $131,600.000$ & $13 \%$ \\
\hline
\end{tabular}

Sumber : Badan Pendapatan Daerah Kab. Gowa, Dinas Kebudayaan dan Pariwisata Kabupaten Pangkep, dan Dinas Kebudayaan dan Pariwisata Kota Makassar

Tabel 2. Matriks Internal Factors Evaluation (IFE)

\begin{tabular}{|c|c|c|c|c|}
\hline INDIKATOR & FAKTOR INTERNAL & $\begin{array}{l}\text { BOBOT } \\
\text { (a) }\end{array}$ & $\begin{array}{l}\text { RATING } \\
\text { (b) }\end{array}$ & $\begin{array}{l}\text { SKOR } \\
(\mathrm{a} \times \mathrm{x})\end{array}$ \\
\hline \multicolumn{5}{|l|}{ KEKUATAN } \\
\hline $\mathrm{A}$ & Objek wisata yang beraneka ragam & 0.0598 & 3.4 & 0.2033 \\
\hline $\mathrm{B}$ & $\begin{array}{l}\text { Objek yang dikenal secara nasional } \\
\text { maupun internasional }\end{array}$ & 0.0735 & 3.6 & 0.2646 \\
\hline $\mathrm{C}$ & Keunikan objek wisata & 0.0664 & 3.2 & 0.2125 \\
\hline $\mathrm{D}$ & $\begin{array}{l}\text { SDM memiliki kompetensi } \\
\text { dibindangnya }\end{array}$ & 0.0696 & 3.4 & 0.2368 \\
\hline $\mathrm{E}$ & $\begin{array}{l}\text { Aksesibilitas disetiap objek wisata } \\
\text { lancar }\end{array}$ & 0.0735 & 3.2 & 0.2351 \\
\hline $\mathrm{F}$ & Pelayanan yang baik & 0.0762 & 3.4 & 0.2591 \\
\hline \multirow[t]{2}{*}{$\mathrm{G}$} & Pemasaran dilakukan secara optimal & 0.0817 & 3.6 & 0.2942 \\
\hline & Subtotal & 0.5007 & & 1.7056 \\
\hline \multicolumn{5}{|l|}{ KELEMAHAN } \\
\hline $\mathrm{H}$ & $\begin{array}{l}\text { Tarif retribusi disetiap objek wisata } \\
\text { kecil }\end{array}$ & 0.0790 & 1.8 & 0.1421 \\
\hline I & Objek penerimaan retribusi sedikit & 0.0812 & 1.4 & 0.1136 \\
\hline $\mathrm{J}$ & Kurangnya SDM & 0.0636 & 2 & 0.1271 \\
\hline $\mathrm{K}$ & $\begin{array}{l}\text { Sarana dan Prasarana belum } \\
\text { memadai }\end{array}$ & 0.0861 & 1.6 & 0.1377 \\
\hline $\mathrm{L}$ & Jarak lokasi wisata jauh & 0.0636 & 2.2 & 0.1398 \\
\hline M & $\begin{array}{l}\text { Proses penyetoran retribusi masih } \\
\text { manual }\end{array}$ & 0.0498 & 2.8 & 0.1394 \\
\hline \multirow[t]{3}{*}{$\mathrm{N}$} & $\begin{array}{l}\text { Ketegasan dalam pemungutan } \\
\text { retribusi masih rendah }\end{array}$ & 0.0762 & 1.8 & 0.1371 \\
\hline & Subtotal & 0.4995 & & 0.9368 \\
\hline & TOTAL & 1.0000 & & 2.6425 \\
\hline
\end{tabular}


Tabel 3. Matriks External Factors Evaluation (IFE)

\begin{tabular}{|c|c|c|c|c|}
\hline INDIKATOR & FAKTOR EKSTERNAL & $\begin{array}{l}\text { BOBOT } \\
\text { (a) }\end{array}$ & $\begin{array}{l}\text { RATING } \\
\text { (b) }\end{array}$ & $\begin{array}{l}\text { SKOR } \\
(\mathrm{a} \times \mathrm{b})\end{array}$ \\
\hline \multicolumn{5}{|l|}{ PELUANG } \\
\hline A & Sifat kepariwisataan yang suistainable & 0.0587 & 2 & 0.1175 \\
\hline $\mathrm{B}$ & $\begin{array}{l}\text { Masih banyak objek retribusi yang belum } \\
\text { dikembangkan }\end{array}$ & 0.0969 & 3.6 & 0.3488 \\
\hline $\mathrm{C}$ & $\begin{array}{l}\text { Kebiajakan pemerintah yang berorientasi } \\
\text { pada sektor pariwisata }\end{array}$ & 0.0968 & 3.8 & 0.3679 \\
\hline $\mathrm{D}$ & $\begin{array}{l}\text { Dukungan masyarakan disekitar objek } \\
\text { pariwsata }\end{array}$ & 0.0914 & 3.4 & 0.3108 \\
\hline $\mathrm{E}$ & $\begin{array}{l}\text { Komitmen pemerintah dalam upaya } \\
\text { peningkatan PAD }\end{array}$ & 0.1014 & 3.8 & 0.3853 \\
\hline $\mathrm{F}$ & Kemajuan teknologi & 0.1004 & 3.8 & 0.3816 \\
\hline & Subtotal & 0.5456 & & 1.9119 \\
\hline \multicolumn{5}{|l|}{ TANTANGAN } \\
\hline $\mathrm{G}$ & $\begin{array}{l}\text { Kesadaran pengunjung tentang wajib } \\
\text { retribusi masih rendah }\end{array}$ & 0.1004 & 1.2 & 0.1205 \\
\hline $\mathrm{H}$ & $\begin{array}{l}\text { Kesadaran pengunjung dalam menaati } \\
\text { peraturan masih rendah }\end{array}$ & 0.0721 & 2.8 & 0.2017 \\
\hline I & $\begin{array}{l}\text { Beberapa objek wisata bergantung pada } \\
\text { kondisi alam }\end{array}$ & 0.0758 & 3.2 & 0.2425 \\
\hline $\mathrm{J}$ & $\begin{array}{l}\text { Tuntutan terhadap kualitas objek } \\
\text { pariwsiata }\end{array}$ & 0.0976 & 2.2 & 0.2147 \\
\hline \multirow[t]{3}{*}{$\mathrm{K}$} & $\begin{array}{l}\text { Objek pariwisata milik swasta } \\
\text { berkembang pesat }\end{array}$ & 0.1085 & 1.2 & 0.1302 \\
\hline & Subtotal & 0.4544 & & 0.9096 \\
\hline & TOTAL & 1.0000 & & 2.8215 \\
\hline
\end{tabular}




\begin{tabular}{|c|c|c|}
\hline & $\begin{array}{l}\text { Kekuatan (S) } \\
\text { 1. Objek wisata yang beraneka } \\
\text { ragam } \\
\text { 2. Objek yang dikenal secara } \\
\text { nasional maupun } \\
\text { internasional } \\
\text { 3. Keunikan objek wisata } \\
\text { 4. SDM memiliki kompetensi } \\
\text { dibidangnya } \\
\text { 5. Aksesibilitas disetiap objek } \\
\text { wisata lancar } \\
\text { 6. Pelayanan yang baik } \\
\text { 7. Pemasaran dilakukan secara } \\
\text { optimal }\end{array}$ & $\begin{array}{l}\text { Kelemahan (W) } \\
\text { 1. Tarif retribusi disetiap objek } \\
\text { wisata kecil } \\
\text { 2. Objek penerimaan retribusi } \\
\text { sedikit } \\
\text { 3. Kurangnya SDM } \\
\text { 4. Sarana dan Prasarana belum } \\
\text { memadai } \\
\text { 5. Jarak lokasi wisata jauh } \\
\text { 6. Proses penyetoran retribusi } \\
\text { masih manual } \\
\text { 7. Ketegasan dalam } \\
\text { pemungutan retribusi masih } \\
\text { rendah }\end{array}$ \\
\hline $\begin{array}{l}\text { Peluang }(\mathrm{O}) \\
\text { 1. Sifat kepariwisataan } \\
\text { yang suistainable } \\
\text { 2. Masih banyak objek } \\
\text { retribusi yang belum } \\
\text { dikembangkan } \\
\text { 3. Kebijakan pemerintah } \\
\text { yang berorientasi pada } \\
\text { sektor pariwisata } \\
\text { 4. Dukungan masyarakat } \\
\text { di sekitar objek } \\
\text { pariwisata } \\
\text { 5. Komitmen pemerintah } \\
\text { dalam upaya } \\
\text { peningkatan PAD } \\
\text { 6. Kemajuan teknologi }\end{array}$ & $\begin{array}{l}\text { (S7, O3, O5, O6) } \\
\text { Meningkatkan kegiatan } \\
\text { pemasaran dengan melalui } \\
\text { teknologi dan dukungan } \\
\text { pemerintah }\end{array}$ & $\begin{array}{l}(\mathrm{W} 2, \mathrm{O} 2, \mathrm{O} 3, \mathrm{O} 5) \\
\text { Penambahan sumber } \\
\text { penerimaan retribusi baik berupa } \\
\text { penambahan objek pariwsiata } \\
\text { maupun objek pendukung } \\
\text { kegiatan pariwisata. }\end{array}$ \\
\hline Ancaman $(\mathrm{T})$ & $\begin{array}{l}\text { (S4, S6, T1, T4, T5) } \\
\text { Alokasi Sumber Daya Manusia } \\
\text { (SDM) sesuai dengan } \\
\text { kompetensi yang dimiliki }\end{array}$ & $\begin{array}{l}\text { (W7, T1,T4) } \\
\text { Tegas dalam melakukan } \\
\text { pungutan reteribusi }\end{array}$ \\
\hline
\end{tabular}




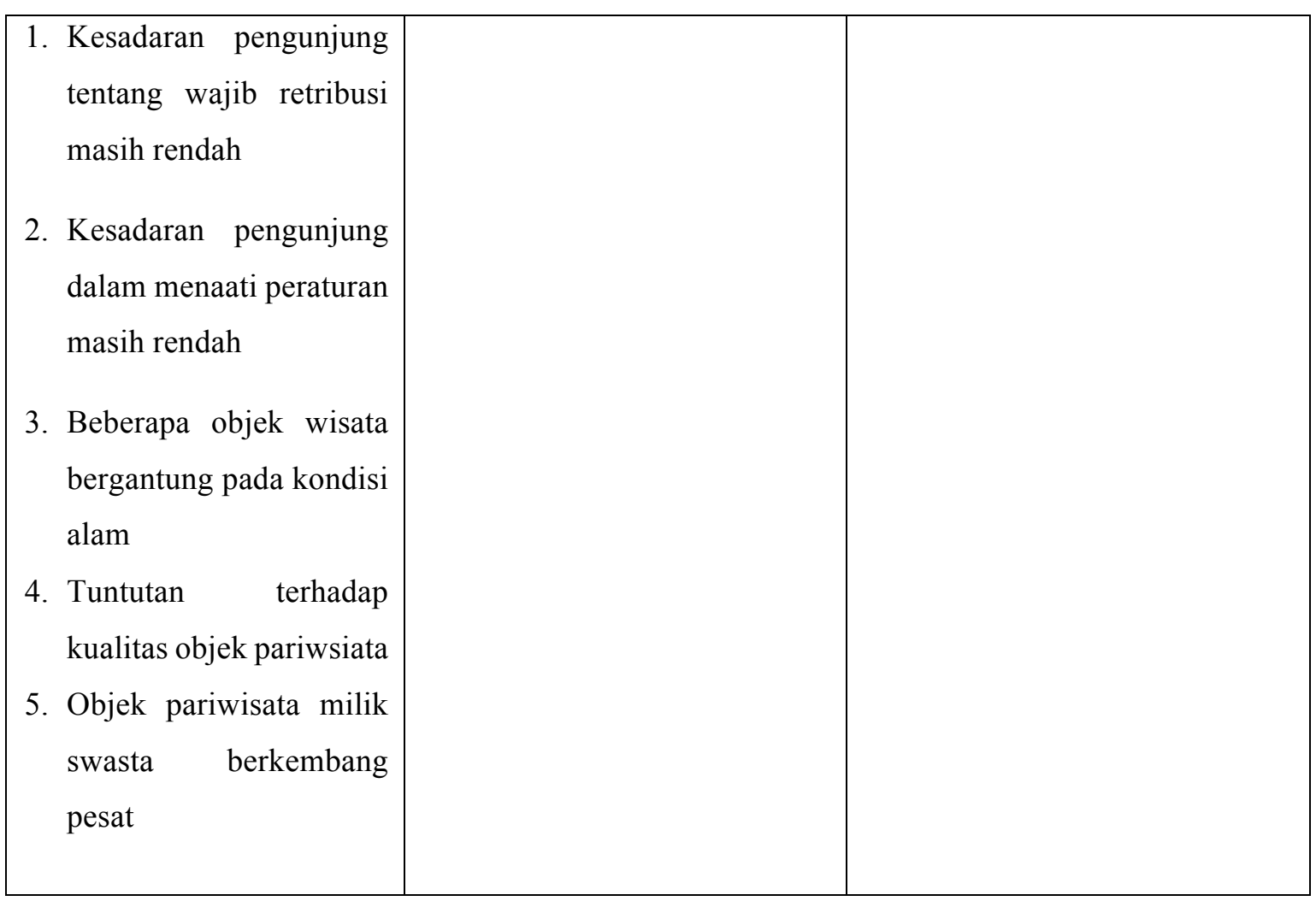

Tabel 5. Matriks QSPM

\begin{tabular}{clc}
\hline No & \multicolumn{1}{c}{ Strategi } & $\begin{array}{c}\text { Jumlah total nilai } \\
\text { daya tarik (STAS) }\end{array}$ \\
\hline 1 & $\begin{array}{l}\text { Penambahan sumber penerimaan retribusi baik berupa } \\
\text { penambahan objek pariwisata maupun objek } \\
\text { pendukung kegiatan pariwisata. }\end{array}$ & 5.88 \\
2 & $\begin{array}{l}\text { Alokasi Sumber Daya Manusia (SDM) sesuai dengan } \\
\text { kompetensi yang dimiliki }\end{array}$ & 5.43 \\
3 & Optimalisasi kegiatan pemasaran & 4.65 \\
4 & Peningkatan Kesadaran wajib retribusi & 4.00 \\
\hline
\end{tabular}

